\title{
Religious security of the Russian Federation as a reflection object of Philosophy and Religious Studies
}

\author{
Artem Zhukov ${ }^{1, *}$, and Tatyana Bernyukevich ${ }^{1,2}$ \\ ${ }^{1}$ Transbaikal State University, 672039, Aleksandro-Zavodskaya str., 30, Chita, Russia \\ ${ }^{2}$ Moscow State University of Civil Engineering (National Research University), 129337, \\ Yaroslavskoye shosse, 26, Moscow, Russia
}

\begin{abstract}
The article is devoted to the philosophical aspects of the discourse on religious security on the territory of the Russian Federation, where religious organizations are recognized as one of the possible threats to modern society. The authors of the article prove that the specificity of threats on the part of religious organizations should be that their motive is to be a doctrine. The article justifies the fact that the commission of unlawful actions by a religious organization is most often justified not by dogma, but by material, secular motives. This leads to the fact that this activity is evaluated in accordance with the degree of harm caused as an extremist one. The novelty of the study is that the authors draw attention to the fact that there are religious associations that are recognized as dangerous, despite the fact that they do not carry out unlawful actions. The degree of danger they represent is determined on the basis of the content of religious texts that are recognized as dangerous if it can be proved that the potential threat contained in them can acquire a real character. The result of the article is the proof that the task of secular religious studies and social philosophy should not be efforts aimed at banning religious organizations that represent not a real threat, but only a potential danger, since the main thing in which these sciences are interested is the development of the theory of social adaptation of religion.
\end{abstract}

\section{Introduction}

The national security strategy of the Russian Federation until 2020 draws the attention of citizens to the fact that one of the most dangerous sources of threats to public and state security has been the extremist activities of nationalistic, religious, ethnic, and other organizations and structures aimed at violating the unity and territorial integrity of the Russian Federation, destabilizing the internal political and social situation in the country [6]. The content of this document directly indicates that religious organizations are one of the possible threats to contemporary society, which makes it urgent to study religion from the security point of view.

*Corresponding author: artem_jukov68@mail.ru 


\section{Literature review}

Religious security is a phenomenon that is analyzed by Social Philosophy, Religious Studies, History, Anthropology, and Sociology. The main issue is the analysis of religious influence on the consciousness of believers. The most important for understanding the problems of the influence of religion on society in religious studies are the reserch by $\mathrm{F}$. Schleiermacher [32], M. Muller [28], E. Cassirer [14], J. Campbell [11], who saw the difference between essence and external forms of religion. In the writings of supporters of the sociological and anthropological approach (R. Barth [1], P. Berger and T. Lukman [9], G. Gance [15], W. James [20], K. Yinger [35], M. Castells [12], N. Luman [25], K. Marx [4], R. Niebuhr [27], E. Fromm [18], J. Richardson [30], J. Habermas [19], K. Jaspers [ 21]), religious consciousness is understood as a phenomenon caused by the social.

Through the prism in which the relations of "one's own" and "other's own" are reflected, anti-cultists' research works are written (D. Groituus [16], A. L. Dvorkin [2], J. Clark [13], R. Lifton [23] M. Lane [26], T. Patrick and T. Dulac [29], M. Singer [33], M. Ferguson [17]). Despite the criticism of professional religious scholars (E. Barker [8], D. Keli [22], B. Wilson [36]), anti-cultism has a significant impact on mass consciousness. In general, the analysis shows that there is an issue of choosing adequate approaches to religious security at present.

The main goal of the study is to conduct a structural and functional analysis of religious security on the territory of Russia in the context of the methodology of secular Religious Studies and Social Philosophy.

\section{Materials and methods}

The research materials and methods are formed by philosophical, philosophical-religious, and sociological concepts that allow interpreting a polysemantic material as a result of a complex interdisciplinary study, taking into account empirical data. The theoretical basis is the provisions of the religious consciousness on the social nature in the teachings of $\mathrm{L}$. Feuerbach, M. Weber, and E. Durkheim. The methodological basis of the work is a universalist approach that allows to consider the processes of cultural transformation in the context of analyzing worldview universalities. A comparative approach is aimed at analyzing the correlation of the general and specific in the processes of social influence on the consciousness of believers. A comprehensive approach applied in the study of contemporary processes of spreading social influence on believers in virtual space. The research uses a system of methods, including (a) the typologization of phenomena of social influence; (b) phenomenological ones, with reference to the problem of the formation of meanings arising from the interaction of social, religious ideas and religious consciousness; (c) a method of reconstruction and modeling of the interaction space of social influence and religious consciousness; (d) a method of structural analysis applied to the study of mechanisms and agents of social influence on religious consciousness.

The empirical base of the research includes a set of federal and regional legal documents, journalistic articles. The corpus of documents compiled by articles of the Constitution of the Russian Federation, the Law on Freedom of Conscience and on Religious Associations, the Criminal Code of the Russian Federation provided research with objective data regarding the current state of state-confessional relations. 


\section{Results}

In the practice of social regulation of the processes of inter-confessional interaction on the territory of the Russian Federation, two types of religious associations are classified as extremist organizations that pose a danger to society. First, it is determined that the real source of danger is those unlawful acts of the representatives of religion, which they, as well as other citizens, commit within the limits defined by the criminal legislation. Moreover, in the overwhelming number of cases, the commission of unlawful actions by a religious organization is justified not by dogma, but by political orders or material motives. Therefore, this activity is assessed in accordance as an extremist one, with the degree of harm caused.

However, in the second place, there are religious associations that are recognized as dangerous, despite the fact that they do not carry out unlawful actions. Representations about the danger emanating from them have grounds in the uncertainty characterizing the transcendental source of these religions, as well as the alienation of their institutional form from the level of ordinary believers. In social practice, this alienation is overcome through the dissemination of religious texts that contain information about the transcendental source of religion. However, such communication does not provide verification of its source; therefore, the content of religious texts is the reason for accusations of the danger of a particular religion. The unverifiable nature of beliefs about religion serves as a pretext for attempts to influence the audience in the interests of representatives of competing religious movements, indicating by means of religious texts to mass consciousness, the true meaning of religious phenomena. A consequence of the difference between non-traditional and traditional teachings is the opposition to new religions by traditionalists, who often speak on behalf of science and claim that non-traditional religions are the "sects" and carry the danger as they cannot adequately reflect religious truth. The question of their danger here is often solved by the method of dividing them into "their own," "traditional," and "alien," "non-traditional."

The degree of their danger is determined by the relevant provisions of the Criminal Code of the Russian Federation, the content of which states that the propaganda of social, racial, national, religious or linguistic superiority is prohibited in the territory of the Russian Federation, and propaganda that incites social, racial, national, or religious hatred and enmity [40]. In the development of this constitutional provision, the Criminal Code establishes a ban on public calls for the implementation of extremist activities. Therefore, not every religious text, which is an expression of unconventional religious ideas, can be recognized as dangerous, but one that contains calls for extremism. In general, it is important to note that the specificity of the concept of "religious security" determines the existence of appeals, i.e. not strictly illegal actions, but events that anticipate them.

Thus, the "religious danger" reflected in the Criminal Code is something that exists only as an opportunity. Thus, the real degree of religious danger in the field of moral damage to the religious feelings of believers is debatable, and therefore potential. For the practice of regulation and punishment, this type of danger is always associated with discursiveness and attempts by different parties to prove different interpretations of the same acts. To determine the degree of danger of a religious text, it is resorted not so much to legal as to religious, linguistic, and psychological expertise, which gives a scientific, but far from legal, analysis of the degree of danger of religious texts. At the same time, the answers to the question about the essence of the influence of the same religious texts on society are very different. Hence the main task of the fighters for religious security is to try to convince the mass consciousness and representatives of law enforcement bodies that the nature of a religion is dangerous in itself. Unconventional religions, from the point of view of science, which is called "sectology," are aimed at destroying the "true faith" and seducing a person 
who believed them. Anticulists seek to organize movements aimed at banning religious dissent.

So, representatives of the confessional religious studies believe that the essence of religious revelation, which reflects religious texts, is the existence of a connection with the transcendental beginning. It is determined by an analysis that reveals their conformity to the dogmatics of a particular religion. However, there are a number of studies proving the baselessness of accusations of their danger to society. Most scholars of religion note that the lives of people who have joined the new religions are also natural, like other people who take and take off various important obligations. Secular religious studies consider religion to be only a social phenomenon. Therefore, here the identification of religious danger consists in analyzing the appeals for the implementation of unlawful types of social behavior contained in religious texts. Secular Religious Studies and Social Philosophy should be interested not in collecting evidence of the social danger of those religions that are a priori recognized as unconventional for society, but in developing a theory of social adaptation of religion, where there is a system of interaction between religion and society. In particular, the noteworthy provision is that often accusations of the danger of a religious organization that does not commit unlawful acts are connected with the confrontation between competitors for social influence. Thus, a number of accusations pointing to the danger of non-traditional religions are provoked not by real threats from them, but by the desire to respond to their challenge to the values and institutions dominant in society. Therefore, the processes during which they are subjected to social ostracism are not a battle with the representatives of "antichrist," but an element of the process of their social adaptation, during which non-traditional religious associations, subject to pressure from public opinion, acquire more acceptable forms of behavior, worship, and organization for this society.

\section{Discussion}

The reason for a different understanding of the degree of religious danger is the transcendental nature of religion, and the definitions of the classics in Religious Studies confirm such a claim. According to these descriptions, religion in social space appears in two hypostases, "visible" and "perspective," i.e. imaginary [32]. As a result, in society, religion exists on two levels, one of which is represented by religious phenomena, and the other is a description of these phenomena, which is always an act of alienation associated with the process of individualization and building an unverifiable perspective that organizes the world. Therefore, beliefs about religious danger include beliefs that some of the religious texts can contain hidden and obvious threats to existing order and personality [1, p. 297].

However, there is a certain contradiction here that the danger that comes from religions seems religious only when it is of a potential nature, and when ascertaining the already committed unlawful acts, the religious danger ceases to be potential and becomes not a religious but a real damage. In this case, the religious organizations caused this harm are considered not as religious, but as extremist. An exception is the unlawful act of "insulting the religious feelings of believers," which is clearly religious, but in practice being almost unrecorded, which, nevertheless, is reflected in Article 148 of the Criminal Code as "public actions expressing obvious disrespect for society and committed for the purpose of insulting the religious feelings of believers" [38]. However, this phrase does not specify any criminal consequences that would reflect the onset of damage to the religious feelings of believers. As the practice of applying these provisions shows when discussing the degree of blame that allegedly inflicted moral damage to the religious feelings of the faithful members of the Pussy Riot group, or the Pokémon catcher in the Orthodox church, the 
interpretation of the damage was subjective and depended only on the credibility of the position of the prosecution [37].

This puts the problem on the agenda, the separation of religious associations into "one's own" and "other's own." There are two types of influence of different religions on society, such as "traditional," i.e. "one's own," being understood as "safe"; and "non-traditional," i.e. "alien," being understood as "dangerous." It is believed that the traditionalist type of influence of religion manifests itself when people perceive religion by birth naturally and safely [5]. At the same time, from the point of view of alternative religious associations under conditions of domination of traditional religious consciousness, a person is exposed to the danger of not being saved, as such a person is deprived of freedom of religious choice. This freedom is offered by non-traditional religious movements that first arose at the stage of the emergence of early civilizations in connection with the emergence of new forms of assertion that rivaled the archaic religion. As K. Jaspers believes, they reported the existence of a supersensible world as a guarantee of security and life according to the high faith [21].

However, their opponents believed that the new religions are a tool for implementing dangerous intentions for the society. This led to a statement of the danger of new religions towards the society and their followers [11]. As the source of religious danger, the founders of the new religions, who claimed to have a special level of religious knowledge, were identified. The dominant tradition in society seemed to them as a source of danger and a threat to religious salvation, which was understood as a path that caused great difficulties and was very unusual for their traditional society [9].

At the same time, according to the opinion of such scholars as J. Richardson [30], all world religious traditions originated in the guise of new, non-traditional religions, opposing previous traditions. A long process of adaptation led them to a position where they themselves began to be understood as a tradition, and then they began to pursue the medieval "paganism" that had become "unconventional" and "dangerous" [24]. These accusations led to the perception of "popular religion" as a dangerous "dual belief," which gave rise to radical forms of religious persecution and attempts to achieve religious purity through, in fact, extremist actions. For example, adhering to contemporary criteria, it is quite possible to consider the figures of the Reformation as extremists in terms of formal characteristics; they were never tolerated in relation to other faiths. Nevertheless, for a long time, the interaction of world religions and society has acquired a stable character when, on the one hand, the elite religion was influenced by popular traditions. On the other hand, it influenced the society through various forms of organizations and cults that could be ambiguously evaluated by both participants and scholars; nevertheless, they were in the conditions of relative equilibrium that was characteristic of traditional societies. However, the balance between the religion of society was violated with the onset of modernity, along with which anthropological crisis, globalization and dehumanization came into the culture of society. These tendencies significantly influence the problems of religious security, in the center of which there is the problem of the individual, which, on the one hand, is represented by a powerful man, formed by a technical civilization. The downside of this person is impotence, which is manifested as a desire to avoid personal responsibility and self-developed behavioral guidelines [18]. Also, in contemporary society, a widespread dichotomy was the actualization of the opposition between tradition and innovation. Images associated with exposing the danger of new religious movements spread the anti-cultist trend [36].

For their part, the apologists of "unconventional religiosity" argue that the Western society is threatened by a technological catastrophe, which can save only new doctrine and mysticism [31]. Meanwhile, the specific aspects of the danger in the religious sphere are pointed out by the work of V. Shtepa, who asserts that neither new nor traditional religions 
have preserved a truly religious spirit, cannot claim to be authentic, and, as a result, could guarantee the safety of their believers [7]. This shows that, in practice, it is impossible to expose unambiguous interpretations of their attitude to society, either dangerous or harmless. At the same time, in the practice of regulation of interconfessional interaction, "shortcuts" and simplifications are most often used, helping to separate religions that are considered "their own," "constructive" from religions defined as "strangers," "dangerous" [24, p. 40].

Nevertheless, one cannot say that a religious danger is only a fiction. Among the religious phenomena, there are also those that actually threaten. This applies to religious extremism, whose most vivid manifestations are connected with Islamic fundamentalism in the person of Wahhabis, the Taliban, and a terrorist organization called the "Islamic State" [41]. However, it is important to note that when Islamic extremists commit their crimes, they deal with very specific illegal and also inhuman acts, most of which are not religious in nature, but are associated with destruction, killings, and mass executions.

At the same time, there are a number of other religious organizations that are regarded as extremist, although there are no unlawful and not aimed at destroying people. Such organizations as Jehovah's Witnesses, Muni Unification Church, Krishna Consciousness Society, Scientology, etc., to which, despite the fact that the Russian Federation is a secular democratic state where the principle of freedom of conscience operates, such terminology as "sects" is used

. Despite the absence of outright crimes in their deeds, it is believed that they conduct extremist activities, the essence of which is the manipulation of consciousness [2].

However, researchers of the problem of interaction between religion and society, such as E. Barker [8], conclude that there is no danger of religious influence on the followers of new religions. At the same time, J. Biermans [10] proves that there are many cases confirming the existence of violence within those religions that are considered traditional. The data of the structural study of the processes of religious influence on personality, conducted by J. Sunden, point to a historical reality in which violence and the desire to ensure its existence through strict discipline was characteristic of most modern traditional denominations [24]. In addition, he proves that in Christianity, Buddhism, and Islam, the practice of purposeful cultivation of mysticism is used, contributing to the acquisition of religious experience by people through social learning. Moreover, a similar culture of behavioral regulation exists in a contemporary society, where, according to Yu. Habermas, a purposefully organized system of manipulation and deception is being run by all-powerful multimedia that drags a person into the virtual world [19]. Thus, it is necessary to come to the conclusion that the terminology of "violence against the person" in non-traditional religions does not describe some exceptional practice of destructive influence.

\section{Conclusion}

1. The national security strategy of the Russian Federation indicates that religious organizations are one of the possible threats to contemporary society. Specificity of threats on the part of religious organizations lies in the fact that their motive is to be a doctrine; therefore, religious threats are not a real danger, but a danger that is of a potential nature. The fact is that in cases when illegal actions are already being carried out, they, regardless of the religious background, are assessed in the context of real criminal acts being committed in accordance with the degree of harm done by the extremist, and thus lose the religious status.

2. At the same time, there are also such religious associations that are recognized as dangerous, despite the fact that they do not carry out unlawful actions. The degree of danger they represent is determined on the basis of the content of religious texts that are 
recognized as dangerous if it is possible to prove that the potential danger contained in them can acquire a real character. To determine the degree of danger of religious texts, religious, philological, and psychological examinations are conducted, giving an analysis of the degree of danger of this or that dogma, which is, frankly speaking, far from being purely legal.

3. However, the task of secular Religious Studies and Social Philosophy should not be the efforts aimed at banning a particular religious organization, because the main thing in which these sciences are interested is the development of the theory of social adaptation of religion, according to which newly emerging religions as a result of attempts to spread their influence in society cause a negative reaction, which is a factor affecting the social adaptation of new religions, as the leadership becomes forced to transform the ideology and strategy of their religions, originally aimed at denying the society.

\section{References}

1. R. Bart, Selected works. Semiotics. Poetics (Progress, Moscow, 1989)

2. A. L. Dvorkin, Sectology: eotalitarian sects: ehe experience of systematic analysis (Christian Library, Nizhny Novgorod, 2014)

3. I. Levin, Duality and popular religion in the history of Russia (Indrik, Moscow, 2004)

4. K. Marx, F. Engels, Works (volume 3) (State Publishing House of Political Literature, Moscow, 1962)

5. Yu. I. Mkrtumyan, Basic components of ethnos culture. In Methodological problems of research of ethnic cultures. Yerevan, 1978

6. E. N. Pluzhnikov, Religious extremism in modern Russia: problems of theoretical interpretation and political practice: author's abstract. diss. ... candidate of political science: 23.00.02. (Moscow, 2010)

7. V. Step, Inclusion (Petrozavodsk, 1998)

8. E. Barker, The making of Moonie: choice or brainwashing? (Blackwell Publishers, Oxford, 1993)

9. P. L. Berger, T. Luckmann, The social construction of reality: a treatise in the sociology of knowledge. (Doubleday, New York, 1967)

10. J. Biermans, The odyssey of new religions today: a case study of Unification Church (Edwin Mellen Press, New York, 1988)

11. C. Campbell, Sociological Research, 2(39), 1978

12. M. Castells, The information age: economy, society and culture. Volume I: the rise of the network society (Blackwell Publishers, Cambridge, MA, Oxford UK, 1996)

13. J. Clark, Journal of the American Medical Association (1979)

14. E. Cassirer, The philosophy of symbolic forms: language (Yale University Press, New York, 1955)

15. D. Groothuis, Unmasking the New Age (Downers Grove, New Haven, IL, 1986)

16. M. Ferguson, The Aquarian conspiracy: personal and social transformation in the 1980s. (Los Angeles, 1980)

17. E. Fromm, Escape from freedom (Rinehart and Co. Inc., New York, 1941)

18. J. Habermas, Theorie des kommunikativen Handelns (Suhrkamp, Frankfurt am Main, 1987) 
19. W. James, The varieties of religious experience a study in human nature (eBooks, Adelaide, 2009)

20. K. Jaspers, Die geistige Situation der Zeit (De Gruyter, Berlin, New York, 1999)

21. D. Kelley, Why is the conservative church growing?: A study in the Sociology of Religion from a new prospective (Mercer, Macon, 1986)

22. R. J. Lifton, Thought reform and the psychology of totalism (New York, 1961)

23. Ju. Lotman, B. Uspensky, Binary models in the dynamics of Russian cultural history. In The semiotics of Russian cultural history (Ithaca, N.Y., 1985)

24. N. Luhmann, Two works by N. Luhmann (Wiley, Chichester, 1979)

25. Sh. MacLaine. Dancing in the light (Bantam, New York, 1985)

26. R. Niebuhr, Why the Christian Church is not pacifist? In R. Brown (ed), The essential Reinhold Niebuhr: selected essays and addresses (Yale University Press, New Haven, 1986)

27. M. Müller, Introduction to the Science of Religion (Longmans, Green, London, 1893)

28. T. Patrick, T. Dulack, Let our children go (New York, 1976)

29. J. T. Richardson, Annual Review of the Social Sciences of Religion, 2 (1978)

30. Th. Roszak, Unfinished animal: the Aquarian frontier and the evolution of consciousness (New York, 1975)

31. F. Schleiermacher, D. E. Friedrich, On religion: speeches to its cultured despisers. (Cambridge University Press, Cambridge, 1996)

32. M. Singer, Coming out of the cults (https://www.carolgiambalvo.com/coming-out-ofthe-cults.html, 1979)

33. H. Sundén, Journal for the Scientific Study of Religion, 26, 3 (1987)

34. J. M. Yinger, Religion in the struggle for power: A study in the Sociology of Religion (Duke University Press, 1946)

35. B. R. Wilson, Japanese Journal of Religious Studies, $3 / 4$ (1976)

36. The case of the participants of the group Pussy Riot 2012 (http://mspa7520.ru/delouchastnic-gruppy-pussy-riot-20, 2018)

37. Law on the protection of the feelings of believers from the point of view of a lawyer (http://www.nsad.ru/articles/zakon-o-zashhite-chuvstv-veruyushhih-s-tochki-zreniyaateista, 2018)

38. Article 280. Public appeals for the implementation of extremist activities (http://stykrf.ru/280, 2018)

39. The Criminal Code of the Russian Federation (http://www.consultant.ru/document/cons_doc_LAW_10699/, 2018)

40. On the "Islamic state" (http://www.milhistory.org/topic/245-islamskoe-gosudarstvoorganizatciia-zapreschenn, 2018)

41. A. Bogoviz, S. Lobova, Y. Ragulina, A. Alekseev, V. Garnova, MediaobrazovanieMedia Education, 3, 7-14 (2017) 